\title{
PENGARUH STRATEGI PROMOSI DAN SOCIAL MEDIA TERHADAP MINAT BELI GARSKIN YANG DIMEDIASI WORD OF MOUTH
}

\author{
Dwi Nuvia Ningsih \\ (Program Studi Manajemen, Fakultas Ekonomi Universitas Kanjuruhan, Malang) \\ e-mail:dnovia_n@yahoo.com \\ Candra Wahyu Hidayat \\ Rusno \\ (Program Studi Manajemen, Fakultas Ekonomi, Universitas Kanjuruhan, Malang)
}

\begin{abstract}
ABSTRAK : Penelitian ini bertujuan untuk mengetahui pengaruh secara langsung strategi promosi dan social media terhadap minat beli garskin dan pengaruh secara tidak langsung strategi promosi dan social media terhadap minat beli garskin yang dimediasi word of mouth. Jenis penelitian yang digunakan kuantitatif. Teknik pengambilan sampel menggunakan teknik purposive sampling. Sumber data diperoleh dari penyebaran kuisoner kepada 105 responden konsumen produk garskin. Variabel penelitian yang digunakan strategi promosi dan social media terhadap minat beli yang dimediasi word ofmouth. Metode analisis yang digunakan yaitu analisis path atau analisis jalur. Hasil analisis menunjukkan secara simultan strategi promosi dan social media yang dimediasi word of mouth menunjukkan berpengarauh positif dan signifikan terhadap minat beli garskin. Secara parsial strategi promosi berpengaruh sebesar 0,001 dan social media berpengaruh sebesar 0,002 terhadap word of mouth, strategi promosi dan social media berpengaruh signifikan terhadap minat beli dan word of mouth berpengaruh signifikan terhadap minat beli garskin.
\end{abstract}

Kata kunci - Strategi Promosi, Social Media, Word Of Mouth, Minat Beli

\section{PENDAHULUAN}

Perkembangan era teknologi telah menciptakan lahirnya era digital sehingga menyebabkan manusia ketergantungan terhadap teknologi salah satunya adalah dengan penggunaan internet. Munculnya internet telah mengubah cara manusia dalam berkomunikasi, ketersedian jaringan internet yang semakin baik bagi masyarakat akan memudahkan anggota masyarakat untuk berkomunikasi (Hermawan, 2012). Seiring dengan perkembangan era teknologi yang semakin canggih dari waktu ke waktu, saat ini penggunaan internet sudah tiak asing lagi untuk memasarkan suatu produk.

Pemasaran dengan strategi promosi melalui internet dengan social media (jejaring sosial) memiliki peluang yang besar, dapat memberikan konstribusi yang lebih besar, meningkatkan penjualan secara luas dan tidak memerlukan biaya pemasaran yang mahal. Social media merupakan bagian penting dari strategi penjualan, pelayanan, komunikasi dan pemasaran yang lebih besar dan lebih lengkap serta merefleksikan dan menyesuaikan diri dengan pasar dan orang-orang yang mengartikannya (Solis, 2010). Melihat banyaknya pengakses social media di Indonesia melalui melalui smartphone, terbukti bahwa pengguna internet di Indonesia menggunakan social media menjadi sarana informasi yang diperlukan. Salah satunya pengguna Instagram.

Hal ini bisa menjadi peluang yang baik untuk para pebisnis yang ingin mengembangkan perusahaannya di dunia maya, salah satunya dibidang industri printing, salah satu produknya berupa garskin. Garskin atau Skin Protector adalah stiker yang dibuat untuk memberikan efek gambar khusus pada handphone atau gadget, garskin berfungsi untuk menutupi casing HP, melindungi body HP dari goresan yang sering terjadi karena ketidaksengajaan yang dilakukan oleh manusia, sekaligus memperindah dan mempercantik tampilan HP atau gadget tersebut (Saputra, 2013). 
Jejaring sosial yang berkembang saat ini akan terbentuk proses komunikasi strategi pemasaran yang efektif yaitu word of mouth. Word of mouth merupakan jenis promosi yang ampuh, efektif dan tidak memerlukan biaya yang mahal. Word of mouth merupakan pujian, rekomendasi dan komentar pelanggan sekitar pengalaman mereka atas layanan jasa dan produk yang betul-betul mempengaruhi keputusan pelanggan atau perilaku pembelian mereka (Hasan, 2010). Adanya orang yang memperbincangkan produk garskin, secara tidak langsung orang tersebut mempengaruhi konsumen lain untuk mencari tahu informasi bahkan membeli produk garskin.

Hal ini seperti penelitian yang dilakukan Giri Maulana Arief, Heppy Milliayani (2015), penelitian menunjukkan besarnya pengaruh pemasaran melalui social media marketing yang terdiri dari sub variabel context, communication, collaboration, connection terhadap minat beli konsumen. Pemasaran berbasis social media memiliki pengaruh yang positif dan signifikan terhadap minat beli konsumen produk Sugar Tribe.

Munculnya pesaing yang menjual garskin di social media, kini semakin sedikit yang konsumen yang mengandalkan iklan yang dibuat perusahaan, konsumen beralih ke word of mouth karena lebih dapat diandalkan dan dipercaya. Dengan melihat fenomena di atas, maka peneliti tertarik untuk melakukan penelitian dengan judul "Pengaruh Strategi Promosi Dan Social Media Terhadap Minat Beli Garskin Yang Dimediasi Word Of Mouth".

\section{TINJAUAN PUSTAKA Word Of Mouth}

Menurut Tjiptono (2012), mengemukakan bahwa word of mouth merupakan pernyataan secara operasional maupun non personal yang disampaikan oleh orang lain selain penyedia layananan kepada pelanggan. Menurut Harjadi (2008) word of mouth terdiri dari tiga level talking, promoting dan selling. Menurut Hoskins (2007) word of mouth terdiri dari dua faktor yaitu faktor emosional dan faktor kognisi.

Menurut Sernovitz (2012) terdapat lima elemen dasar yang harus diperhatikan dalam menggunakan WOM yang menguntungkan, yaitu talkers (pembicara), topics (topik), tools (alat), talking part (partisipasi) dan tracking (pengawasan).

\section{Minat Beli}

Menurut Simamora (2014) minat beli adalah sesuatu yang pribadi dan berhubungan dengan sikap individu yang berminat terhadap suatu objek akan mempunyai kekuatan atau dorongan untuk melakukan serangkaian tingkah laku untuk mendekati atau mendapatkan objek. Menurut Winkel (2014) faktor-faktor yang mempengaruhi minat beli konsumen dibagi menjadi dua kelompok diantaranya minat secara intriksik dan minat secara ekstristik.

Menurut Lucas dan Britt (2012) indikator minat beli ialah perhatian (attention), ketertarikan (interest), keinginan (desire) dan keyakinan (convition).

\section{Strategi Promosi}

Menurut Kotler dan Amstrong (2008) strategi promosi adalah logika pemasaran dimana unit bisnis berharap untuk menciptakan nilai dan memperoleh keuntungan dari hubungan dengan konsumen. Tujuan strategi promosi menurut Kuncoro (2010) terbagi menjadi tiga jenis:

1. Memberikan informasi pelanggan tentang produk atau fitur baru

2. Mengingatkan pelanggan tentang merk perusahaan

3. Mempengaruhi pelanggan untuk membeli

Menurut Kotler dan Keller (2016) indikator-indikator strategi promosi diantaranya adalah periklanan (advertising), penjualan secara tatap muka (personal selling), publisitas (publisity), promosi penjualan (sales promotion) dan pemasaran langsung (direct marketing).

\section{Social Media}

Menurut Thoyibie (2010) social media adalah konten yang berisi informasi yang dibuat oleh orang yang memanfaatkan teknologi penelitian, sangat mudah diakses dan dimaksudkan untuk memfasilitasi komunikasi, pengaruh dan interaksi dengan sesama dan khalayak umum.

Menurut Adityo (2011) terdapat dua indikator dalam social media yaitu kemudahan dalam menggunakan teknologi dan kepercayaan pembeli terhadap penjual online.

\section{TINJAUAN EMPIRIS}

Peneliti juga melampirkan penelitian-penelitian terdahulu yang berkaitan dengan judul penelitian yaitu pengaruh strategi promosi dan social media terhadap minat beli garskin yang dimediasi word of mouth. Berikut ringkasan penelitian terdahulu: 
Pengaruh Strategi Promosi Dan Social Media Terhadap Minat Beli Garskin Yang Dimediasi Word Of Mouth

1. Arief dan Milliayanni (2015) yang berjudul Pengaruh Social Media Marketing Melalui Instagram Terhadap Minat Beli Konsumen Sugar Tribe, dengan menggunakan model regresi linier berganda. Menggunakan teknik

penentuan sampel menggunakan metode convience sampling. Pengumpulan data dilakukan penyebaran kuisoner sebanyak 385 responden dengan 19 item pertanyaan.

2. Pribadi dan Susilawati (2018) yang berjudul Pengaruh Kemampuan E-commerce dan Promosi di Media Sosial Terhadap Kinerja Pemasaran, sampel dalam penelitian adalah pedagang di Pasar Pagi Kota Tegal yang berjumlah 100 responden. Dengan menggunakan analisis regresi.

3. Indrawijaya (2012) yang berjudul Pengaruh Kualitas Produk dan Word Of Mouth Terhadap Keputusan Konsumen Dalam Pembelian Roti Manis Pada Industri Kecil di Kabupaten Sarolangun. Pengambilan sampel menggunakan accidental sampling sebesar 80 responden. Dengan cara membagikan kuisoner secara langsung dan melakukan wawancara.

Berikut kerangka konseptual dalam penelitian ini:

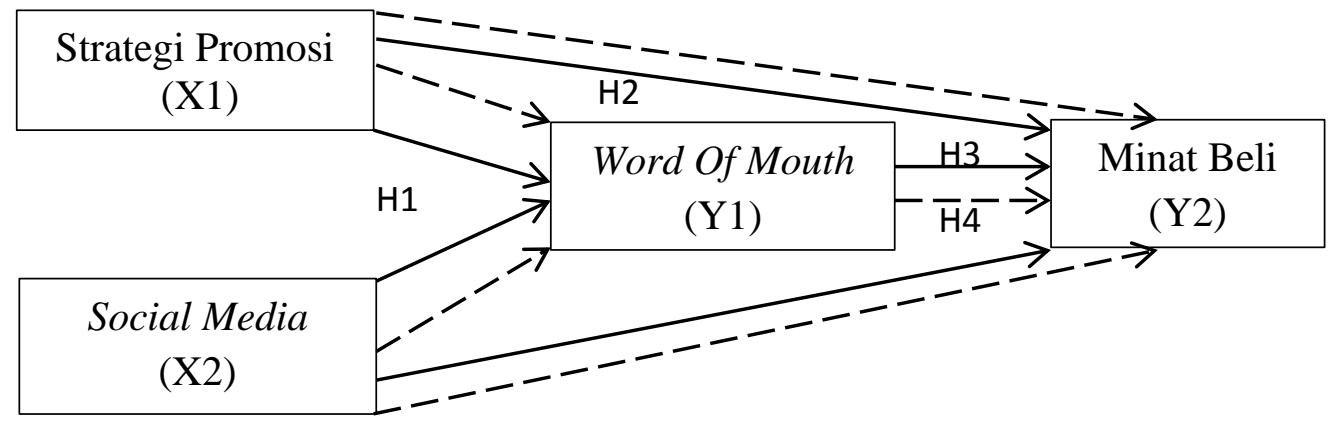

Hipotesis penelitian:

1 : Terdapat pengaruh strategi promosi dan social media terhadap minat beli produk garskin di Kota Malang

2 : Terdapat pengaruh strategi promosi dan social media terhadap word of mouth produk garskin di Kota Malang

3 : Terdapat pengaruh word of mouth terhadap minat beli produk garskin di Kota Malang

4 : Terdapat pengaruh strategi promosi dan social media yang dimediasi word of mouth terhadap minat beli produk garskin di Kota Malang

\section{METODE}

Penelitian ini menggunakan penelitian explanatory research yaitu penelitian yang bertujuan untuk menganalisis hubungan-hubungan antara satu variabel dengan variabel lainnya (Husein, 2008). Populasi dalam penelitian ini diambil dari seluruh konsumen yang membeli produk garskin di Kota Malang sebanyak 105 responden, dengan teknik pengambilan purposive sampling. Jenis dan sumber data dari penelitian ini adalah data kuantitatif dan teknik pengumpulan data dengan menyebarkan kuisoner. Alat dari penelitian ini adalah analisis path (analisis jalur). Analisis ini bertujuan untuk mengetahui pengaruh mengalisis hubungan sebab akibat antara satu variabel dengan variabel lain untuk sampai pada variabel dependen terakhir, harus lewat jalur langsung atau melalui variabel mediasi. Penelitian ini terdiri dari empat variabel yaitu word of mouth (Y1), minat beli (Y2), strategi promosi (X1) dan social media (X2). Penelitian ini menggunakan uji asumsi klasik yang terdiri dari uji normalitas dan uji heterosdesitisitas. Dan uji hipotesis terdiri dari dari uji F (simultan), uji T (parsial) dan uji koefisien determinasi.

\section{PEMBAHASAN}

\section{UJI ASUMSI KLASIK}

Uji Normalitas 
Pengaruh Strategi Promosi Dan Social Media Terhadap Minat Beli Garskin Yang Dimediasi Word Of Mouth Dapat dilihat bahwa perolehan hasil uji normalitas menunjukkan data yang diperoleh berada disekitar garis diagonal dan menyebar mengikuti garis diagonal hal ini menunjukkan bahwa data tersebut dikatakan normal dan model tersebut layak digunakan.

\section{Uji Heteroskedastisitas}

Uji heteroskedastisitas yang dilakukan penguji dapat dilihat scatterplot diatas terlihat titik-titik menyebar secara acak tidak membentuk pola tertentu, artinya pada penelitian ini tidak terjadi gejala heteroskedastisitas.

\section{Analisis Jalur}

1. Pengaruh Langsung Variabel $\mathrm{X}_{1}$ terhadap $\mathrm{Y} 2$

$\mathrm{X}_{1} \longrightarrow \mathrm{Y} 2=0,286$

Artinya, variabel Strategi Promosi memberikan kontribusi pengaruh terhadap Minat Beli sebesar 28,6\%

2. Pengaruh Langsung $\mathrm{X}_{2}$ terhadap $\mathrm{Y} 2$

$\mathrm{X}_{2} \longrightarrow \mathrm{Y}=0,289$

Artinya, variabel Social Media memberikan kontribusi pengaruh terhadap Minat Beli sebesar 28,9\%

3. Pengaruh Tidak Langsung $\mathrm{X}_{1}$ dimediasi $\mathrm{Y} 1$ terhadap $\mathrm{Y} 2$

$\mathrm{X}_{1} \longrightarrow \mathrm{Y} 1 \longrightarrow \mathrm{Y} 2=0,194 \times 0,244=0,047$

Artinya, pengaruh variabel Strategi Promosi dimediasi Word of Mouth terhadap Minat Beli sebesar 4,7\%

4. Pengaruh Tidak Langsung $\mathrm{X}_{2}$ dimediasi $\mathrm{Y} 1$ terhadap $\mathrm{Y} 2$

$\mathrm{X}_{2} \longrightarrow \mathrm{Y} 1 \longrightarrow \mathrm{Y} 2=0,398 \times 0,244=0,097$

Artinya, pengaruh variabel Social Media dimediasi Word Of Mouth terhadap Minat Beli sebesar 9,7\%

5. Pengaruh Total

Ptotal $_{1}=\mathrm{PL}_{1}+\mathrm{PTL}_{1}$

Ptotal $_{1}=0,286+0,047=0,333$

Artinya, pengaruh total 1 sebesar $33,3 \%$

6. Pengaruh $\mathrm{Total}_{2}$

Ptotal $_{2}=\mathrm{PL}_{2}+\mathrm{PTL}_{2}$

Ptotal $_{2}=0,289+0,097=0,386$

Artinya, pengaruh total ${ }_{1}$ sebesar $38,6 \%$

\section{UJI HIPOTESIS}

\section{Uji t (Parsial)}

\section{Hipotesis 1}

Hasil analisis regresi pada tabel diatas terlihat bahwa strategi promosi (X1) menunjukkan nilai signifikansi sebesar $0,001<0,05$, berarti ada pengaruh yang signifikan dari variabel strategi promosi $(\mathrm{X} 1)$ terhadap minat beli (Y2).

Hasil analisis regresi pada tabel diatas terlihat bahwa social media (X2) menunjukkan nilai signifikansi sebesar $0,002<0,05$, berarti ada pengaruh yang signifikan dari variabel social media (X2) terhadap minat beli (Y2).

Hasil analisis regresi pada tabel diatas dapat disimpulkan bahwa $\mathrm{H} 1$ diterima.

\section{Hipotesis 2}

Hasil analisis regresi pada tabel diatas terlihat bahwa strategi promosi (X1) menunjukkan nilai signifikansi sebesar $0,038<0,05$, berarti ada pengaruh yang signifikan dari variabel strategi promosi $(\mathrm{X} 1)$ terhadap word of mouth (Y1).

Hasil analisis regresi pada tabel diatas terlihat bahwa social media (X2) menunjukkan nilai signifikansi sebesar $0,000<0,05$, berarti ada pengaruh yang signifikan dari variabel social media (X2) terhadap word of mouth (Y1).

Hasil analisis regresi pada tabel diatas dapat disimpulkan bahwa $\mathrm{H} 2$ diterima.

\section{Hipotesis 3}


Pengaruh Strategi Promosi Dan Social Media Terhadap Minat Beli Garskin Yang Dimediasi Word Of Mouth Hasil analisis regresi pada tabel diatas terlihat bahwa word of mouth (Y1) menunjukkan nilai signifikansi sebesar $0,007<0,05$, berarti ada pengaruh yang signifikan dari variabel word of mouth (Y1) terhadap minat beli (Y2).

Hasil analisis regresi pada tabel diatas dapat disimpulkan bahwa $\mathrm{H} 3$ diterima.

Uji f (Simultan)

Hipotesis 4

Hasil analisis regresi pada tabel diatas terlihat bahwa strategi promosi (X1), social media (X2) dimediasi word of mouth (Y1) terhadap minat beli (Y2) menunjukkan nilai F hitung 22,858 > F tabel 2,687 dengan nilai signifikansi

sebesar $0,000<0,05$, berarti ada pengaruh yang signifikan dari variabel strategi promosi (X1), social media (X2) dimediasi word of mouth (Y1) terhadap minat beli (Y2).

Hasil analisis regresi pada tabel diatas dapat disimpulkan bahwa $\mathrm{H} 4$ diterima.

\section{Koefisien Determinasi}

Dapat diketahui bahwa nilai koefisien determinasi ( Adjusted $R$ Square) yakni sebesar 0,387. Berdasarkan nilai tersebut dapat dilihat bahwa kinerja karyawan dipengaruhi oleh promosi, social media dimediasi word of mouth terhadap minat beli sebesar 38,7\%. Sedangkan sisanya minat beli dipengaruhi oleh faktor-faktor di luar promosi, social media dan word of mouth.

\section{PEMBAHASAN}

\section{Pengaruh Strategi Promosi dan Social Media terhadap Word Of Mouth}

Berdasarkan hasil pengujian hipotesis ada pengaruh yang signifikan dari strategi promosi (X1) dan variabel social media (X2) terhadap word of mouth (Y1). Dari hasil penelitian variabel strategi promosi dan social media dinyatakan berpengaruh terhadap word of mouth. Artinya semakin baik promosi yang dilakukan dan semakin positif informasi yang disampaikan di social media maka akan berpengaruh positif pada word of mouth yang dilakukan oleh konsumen produk garskin.

\section{Pengaruh Strategi Promosi dan Social Media terhadap Minat Beli}

Berdasarkan hasil pengujian hipotesis variabel strategi promosi (X1) dan social media (X2) berpengaruh terhadap Minat Beli (Y2). Strategi promosi dan social media mampu menciptakan image baik atau image buruk terhadap minat beli produk garskin, praktek pemasaran melalui social media mulai berkembang dan digunakan sebagai alat pemasaran produk mempromosikan merek dan brand suatu perusahaan.

\section{Pengaruh Word Of Mouth terhadap Minat Beli}

Hasil analisis regresi menunjukkan bahwa ada pengaruh yang signifikan dari variabel word of mouth (Y1) terhadap minat beli (Y2). Word of mouth dilakukan agar terjadi komunikasi dari orang ke orang antara sumber pesan penerima pesan dimana penerima pesan menerima pesan dengan suka rela mengenai suatu produk, pelayanan atau merek.

\section{Pengaruh Strategi Promosi dan Social Media terhadap Minat Beli Yang Dimediasi Word Of Mouth}

Hasil analisis regresi menunjukkan bahwa strategi promosi (X1), social media (X2) yang dimediasi word of mouth (Y1) terhadap minat beli (Y2) berarti ada pengaruh yang signifikan dari variabel strategi promosi (X1), social media (X2) yang dimediasi word of mouth (Y1) terhadap minat beli (Y2). Apabila produk yang dihasilkan perusahaan sesuai dengan apa yang diharapkan konsumen untuk memuaskan kebutuhan dan keinginan, maka produk tersebut mampu menarik minat untuk membeli produk garskin. Bila konsumen puas akan produk dapat dipastikan maka pembelian berikutnya akan membeli produk dengan merek tersebut lagi.

\section{KESIMPULAN}

1. Ada pengaruh strategi promosi dan social media secara signifikan terhadap word of mouth produk garskin di Kota Malang.

2. Ada pengaruh strategi promosi dan social media secara signifikan terhadap minat beli produk garskin di Kota Malang.

3. Ada pengaruh word of mouth secara signifikan terhadap minat beli produk garskin di Kota Malang. 
Pengaruh Strategi Promosi Dan Social Media Terhadap Minat Beli Garskin Yang Dimediasi Word Of Mouth

4. Strategi promosi dan social media berpengaruh signifikan terhadap minat beli produk garksin yang dimediasi word of mouth.

\section{SARAN}

1. Bagi Perusahaan

Disarankan untuk perusahaan agar komunikatif dan selalu berinteraksi dengan konsumen, terutama strategi promosi melalui social media. Karena strategi promosi melalui social media merupakan salah satu alat untuk berinteraksi tanpa harus bertatap muka secara langsung dengan konsumen. Perusahaan juga disarankan untuk meningkatkan intensitas word of mouth dalam akun social media. Karena berdasarkan hasil penelitian pengaruh strategi promosi melalui social media terhadap minat beli terbukti termediasi oleh word of mouth,

walaupun efek yang ditimbulkan tidak sebesar strategi promosi dan social media. Word of mouth adalah satu-satunya metode promosi yang berasal dari konsumen, oleh konsumen, dan untuk konsumen. Jadi hal ini sangat perlu diperhatikan.

2. Bagi Peneliti Selanjutnya

Bagi peneliti selanjutnya yang ingin meneliti atau melanjutkan penelitian ini, disarankan untuk meneruskan atau mengembangkan penelitian ini dengan mencari faktor lain yang dapat mempengaruhi minat beli dalam konteks pemasaran melalui strategi promosi dan social media. Selain menggunakan media online untuk menyebarkan kuesioner, penelitian selanjutnya sebaiknya disertai dengan wawancara sehingga data yang diperoleh lebih lengkap dan dapat mengurangi data yang bersifat subyektif.

\section{Daftar Pustaka}

Adityo, Benito. 2011. Analisis Pengaruh Kepercayaan, Kemudahan Dan Kualitas Informasi Terhadap Keputusan Pembelian Secara Online Di Situs Kaskus. Skripsi. Semarang: Program Sarjan Fakultas Ekonomi Universitas Diponegoro

Allsop, Dee T, Bryce R. Basset and James A.Hoskins. 2007. Word Of Mouth Research: Principles and Applications. Journal of Advertising Research

Arief, Millianyani. 2015. Pengaruh Social Media Marketing Melalui Instagram Terhadap Minat Beli Konsumen Sugar Tribe. Vol. 2. No.3

Harjadi, Didik \& Fatmawati Dewi. 2008. Word Of Marketing (WOM) Communication Sebagai Alternatif Kreatif Dalam Komunikasi Pemasaran. Vol.4. No.8

Hasan, Ali. 2010. Marketing Dari Mulut Ke Mulut. Yogyakarta: Media Pressindo

Hermawan, Agus. 2012. Komunikasi Pemasaran. Jakarta: Erlangga

Http://erikbagussaputra.blogspot.com

Husein, Umar. 2008. Metode Penelitian Untuk Skripsi Dan Teksis Bisnis. Jakarta. PT Rajagrafindo Persada Indrawijaya. 2012. Pengaruh Kualitas Produk Dan Word Of Mouth Terhadap Keputusan Konsumen Dalam Pembelian Roti Manis Pada Industri Kecil di Kabupaten Sarolangun

Kotler, Philip and Kevin Lane Keller, 2016. Marketing Managemen, 15th Edition, Pearson Education,Inc.

Kotler, Philip: Amstrong, Gary, 2008. Prinsip-prinsip Pemasaran Jilid I, Erlangga, Jakarta.

Kuncoro, M. 2010. Masalah, Kebijakan, dan Politik, Ekonimika Pembangunan. Jakarta: Penerbit Erlangga.

Lucas, D. B., \& Britt, S.H., 2012. Measuring Advertising Effectiveness McGraw-Hill, New York

Prihadi, Susilawati. 2018. Pengaruh Kemampuan E-commerce Dan Promosi di Media Social Terhadap Kinerja Pemasaran. Vol.3. No.1

Sernovitz, Andy. 2012. Word of Mouth Marketing: How Smart Companies get People Talking, New York. Penerbit: Kaplan Inc.

Simamora, Henry. 2014. Manajemen Sumber Daya Manusia. Yogyakarta: Bagian Penerbitan Sekolah Tinggi Ilmu Ekonomi YKPN

Solis, Brian. 2010. Engage: The Complete Guide for Brand and Businesses to Build Cultivate and Measure Success on The Web. New Jersey: John Wiley \& Sons

Thoyibie, L. 2010. Psikologi Social Media. http//komunikasi-indonesia.org. Diakses tanggal 2 Oktober 2017 Tjiptono, Fandy. 2012. Strategi Pemasaran, Edisi 3. Yogyakarta, Andi.

Winkel, W.S. 2014. Psikologi Pengajaran. Jakarta: Garsindo 